\title{
ANATOMICAL AND ULTRASTRUCTURAL ASPECTS OF LEAF GALLS IN FICUS MICROCARPA L. F. (MORACEAE) INDUCED BY GYNAIKOTHRIPS FICORUM MARCHAL (THYSANOPTERA)
}

\author{
Silvana Cristina P. M. de Souza ${ }^{1}$ \\ Jane Elizabeth Kraus ${ }^{2}$ \\ Rosy Mary S. Isaias ${ }^{3}$ \\ Lea de Jesus Neves ${ }^{4}$
}

Recebido em 21/05/1999. Aceito em 16/12/1999

\begin{abstract}
RESUMO - (Aspectos anatômicos e ultra-estruturais de galhas foliares em Ficus microcarpa L.f. (Moraceae) causadas por Gynaikothrips ficorum Marchal (Thysanoptera)). Galhas foliares são comuns em diversas espécies de Ficus. O objetivo deste trabalho é estudar as alterações estruturais envolvidas na formação das galhas foliares induzidas por Gynaikothrips ficorum (Thysanoptera) em Ficus microcarpa, uma planta ornamental. As galhas de folhas jovens e maduras foram separadas em dois estádios de desenvolvimento, com base na presença de lesões e no grau de dobramento da lâmina. Durante o desenvolvimento da galha formam-se intumescimentos na lâmina tanto nas folhas jovens quanto nas maduras, os quais coincidem com as áreas de hipertrofia celular e hiperplasia dos tecidos. Estes intumescimentos foram detectados em maior quantidade e mais precocemente em folhas jovens, que, por possuirem células menos diferenciadas, mostraram respostas cecidogenéticas mais rápidas. A hipertrofia e, a hiperplasia foram os processos marcantes na ontogênese desta galha, assim como ocorre em outras induzidas por tripes. Entretanto, apesar dos numerosos sítios de alimentação e a grande área de ataque, as galhas foliares de $F$. microcarpa podem ser consideradas rudimentares, pois não se observa a diferenciação de novos tecidos.
\end{abstract}

Palavras-chave - galha foliar, tripes, Ficus microcarpa, Moraceae, anatomia

ABSTRACT - (Anatomical and ultrastructural aspects of leaf galls in Ficus microcarpa L.f. (Moraceae) induced by Gynaikothrips ficorum Marchal (Thysanoptera)). Several species of Ficus present leaf galls and the goal of this research is to study the structural alterations involved in the formation of leaf galls caused by Gynaikothrips ficorum on F. microcarpa, an ornamental plant. The galls of young and mature leaves were separated into two developmental stages based on the presence of lesions on leaf lamina and

'Scholarship of the PIBIC-CNPq, e-mail: silcrist@ zipmail.com.br

2 Instituto de Biociências da Universidade de São Paulo, Departamento de Botânica, C. Postal 11461, CEP 05422-970, São Paulo, SP, Brasil, e-mail: kraus@usp.br (requests for offprints)

3 Instituto de Ciências Biológicas da Universidade Federal de Minas Gerais, Departamento de Botânica, C. Postal 486, CEP 31270-110, Belo Horizonte, MG, Brasil, e-mail rosymary@dedalus.lcc.ufmg.br

4 Museu Nacional da Universidade Federal do Rio de Janeiro, Departamento de Botânica, Quinta da Boa Vista, São Cristóvão, CEP 20940-040, Rio de Janeiro, RJ, Brasil 
the degree of leaf folding. Swellings of the lamina were observed in young and mature leaves during gall development which coincided with the areas of cellular hypertrophy and tissue hyperplasia. Swellings were detected in a greater amount and more precociously on young leaves when compared to mature ones. In young leaves, the cecidogenetic responses were quicker and led to further structural differences because younger cells are not completely differentiated. Cell hypertrophy and tissue hyperplasia were striking processes involved in the ontogenesis of the studied gall, similar to other galls induced by thrips. Nevertheless, in spite of the numerous sites of feeding and the wide area of attack, F. microcarpa galls can be considered rudimentary, since no new tissue differentiation was observed.

Key words - leaf gall, thrips, Ficus microcarpa, Moraceae, anatomy

\section{Introduction}

Several Ficus species present leaf galls. Condit (1969) reported the presence of galls in four species of Ficus, while Mani (1964) reported the existence of leaf galls in 11 such species. Both authors included Ficus microcarpa in their lists. Neves \& Isaias (1987) first reported the presence of gall inducing insects on the flowers of $F$. microcarpa in Brazil. Other studies on Ficus include ontogenetical studies on galls of $F$ religiosa (Raman \& Gopinathan 1987) and F. tomentella (Neves 1987).

Ficus microcarpa has been misidentified many times as $F$. retusa and $F$. benjamina (Mello Filho et al. 1983), probably because of their very similar vegetative characteristics. This species is very widely used for urban landscaping in Brazil, and infestation by Gynaikothrips ficorum (Thysanoptera) has resuted in the death of many specimens (Mello Filho et al. 1983). Even though infestation is currently less intense, it has not been eradicated from major urban centers, such as São Paulo, São Caetano do Sul, and several towns in the state of Rio de Janeiro.

The development of insect galls is dependent upon the continuous presence of the insect, which through mechanical and chemical stimuli induces the plant cells to differentiate in an abnormal way (Mani 1964; Meyer \& Maresquelle 1983), causing several degrees of alteration in the host organ. From an ecological viewpoint, galls are adaptations that have allowed galling organisms to colonize and radiate in several different habitats (Price $e t$ al.

\section{6, 1987; Fernandes \& Price 1988).}

Thrip induced galls are usually leaf galls simpler than those caused by dipterans or hymenopterans (Mani 1964) and relatively are poorly known (Ananthakrishnan 1992). The understanding of the factors that are cause plant tissues to change anatomically and morphologically may shed some light on the intimate biological association between gall inducing agents and host plants. The goal of this research is to study the structural alterations and reactions of plant tissues involved in the formation of the leaf gall induced by $G$. ficorum on F. microcarpa.

\section{Material and methods}

Young and mature healthy and galled leaves of Ficus microcarpa were collected in the Campus of the Universidade de São Paulo (São Paulo, Brazil) and in Quinta da Boa Vista (Rio de Janeiro, Brazil). Leaves from both sites were separated into young and mature leaves based on their location on the branches, size and texture. The position of the leaf was evaluated based on its insertion in the node, considering that the first node was that located next to the stem apex. The length and width of 50 leaves from each site were measured. Galls were separated into two developmental stages based on the presence of lesions on the leaf lamina, and the degree of leaf folding.

For anatomical studies, leaves were fixed in FAA (formalin, acetic acid and ethanol 50\%, $1: 1: 18, \mathrm{v} / \mathrm{v}$ ) (Johansen 1940), submitted to 
dehydration in tert-butyl alcohol series, and included in paraffin, according to the methods described in Kraus \& Arduin (1997). Transverse serial sections - $10 \mu \mathrm{m}$ thick - were stained in basic fuchsin and astra blue (Kraus et al. 1998). For the preparation of epidermal peels, fresh leaves where cut into small pieces, and heated in 50\% nitric acid (Ghouse \& Yunus 1972). In addition the epidermal peels were stained in basic fuchsin and astra blue (Kraus et al. 1998). Phenolic substances were detected by $10 \%$ ferric chloride (Johansen 1940).

Scanning electronic microscopy studies (SEM) were prepared according to methods described in Silveira (1989). The samples were fixed in FAA, dehydrated in ethyl alcohol series, dried at the critical point with $\mathrm{CO}_{2}$, and covered with gold.

\section{Results}

Healthy and galled young leaves - Young healthy leaves presented a light green color, membranous texture and were on an average 1.9 $\pm 0.5 \mathrm{~cm}$ long and $1,1 \pm 0.3 \mathrm{~cm}$ wide (Fig. $1 \mathrm{~A}$ ). Trichomes were present on both leaf surfaces. Fig. 2 shows a trichome on the adaxial surface. Stomata were sparse and only observed on the abaxial surface (Fig. 3).

In the midrib region, the 2-3 layered adaxial epidermis was covered by a thin cuticle. The internal epidermal layer presented larger cells. The parenchyma presented 4-5 layers of cells next to the adaxial portion of the vascular system, which had an elliptical shape and consisted of primary xylem and phloem. The pith was distinct and located inside the vascular

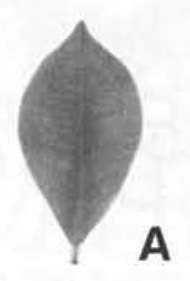

$1 \mathrm{~cm}$
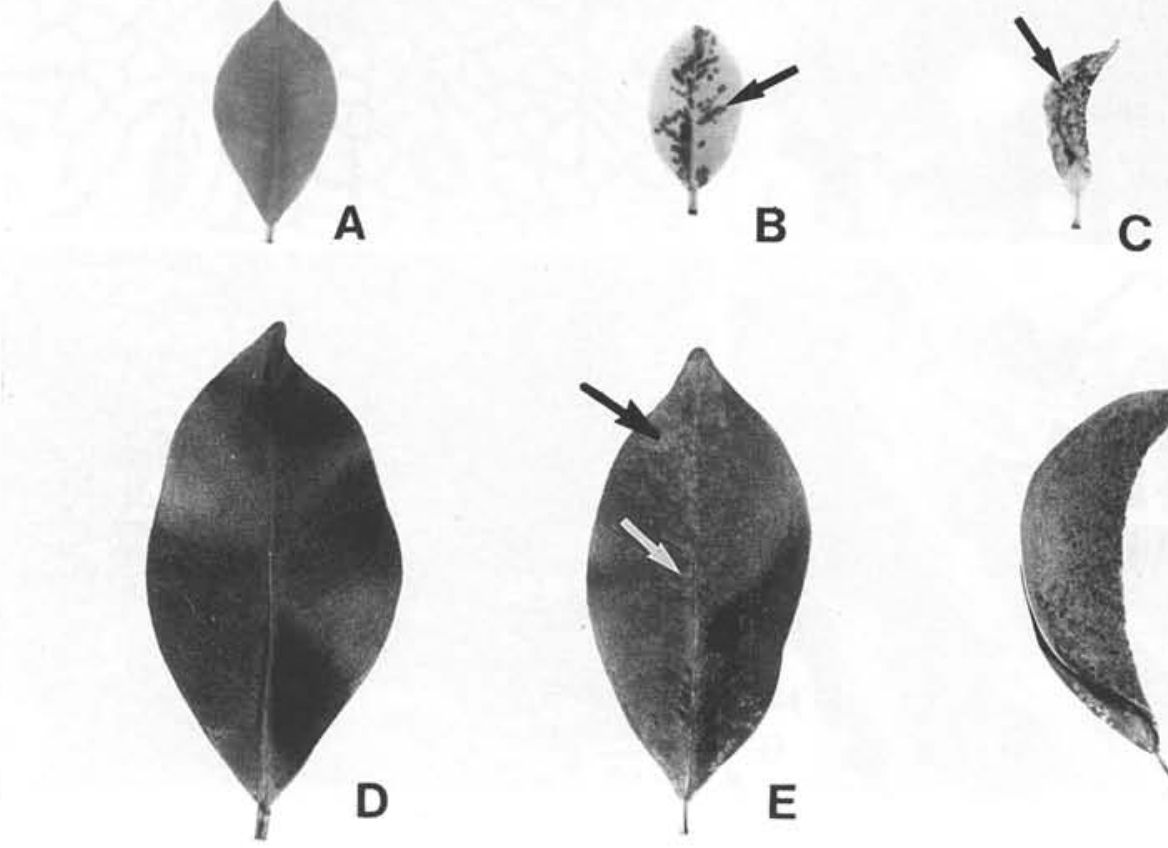

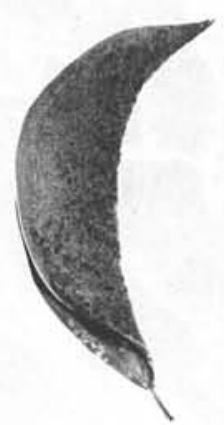

$\mathbf{F}$

Figure 1. Ficus microcarpa. A. Young and healthy leaf; B. Young leaf showing the early stage of gall development. Note the lesions (arrow); C. Young leaf with mature fold gall. Note the lesions (arrow); D. Mature and healthy leaf; E. Mature leaf showing the early stage of gall development. Note the lesions concentrated next to the middle vein (arrows); F. Mature leaf with mature fold gall. 


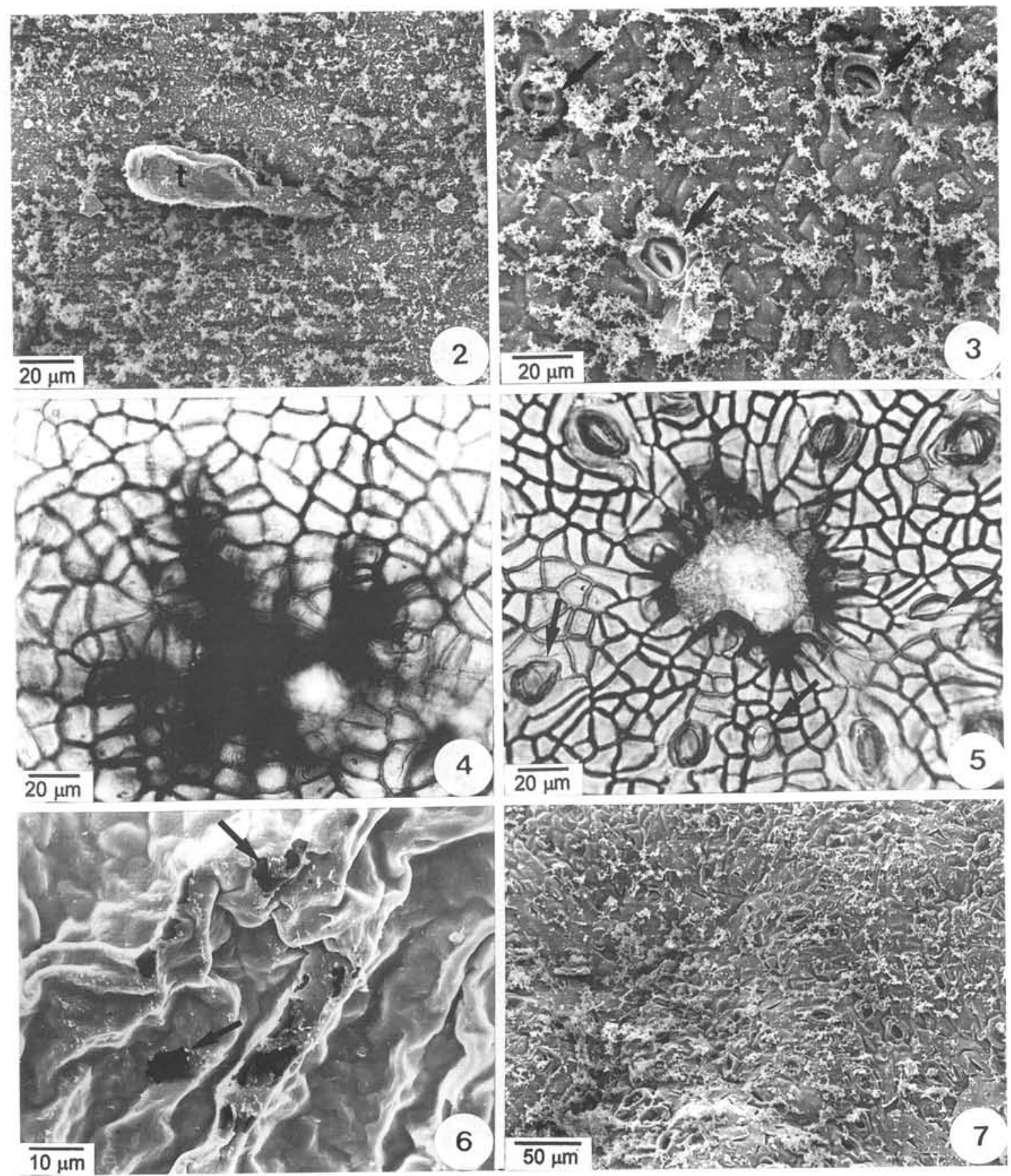

Figures 2-7. Young leaves of Ficus microcarpa. 2, 3, 6 and 7 (SEM). 2. Healthy leaf showing a trichome on abaxial surface; 3 . Healthy leaf showing stomata on the abaxial surface; 4 . Early stage of gall development showing a lesion on the adaxial surface; 5 . Early stage of gall development showing a lesion and the altered stomata (arrows) on the abaxial surface; 6. Mature gall showing perforations (arrows) on the adaxial surface; 7. Mature gall showing altered stomata on the abaxial surface. $(\mathrm{t}=$ trichome). 
system. Several parenchyma cells, full of phenolic compounds, were interspersed among the conductive cells. The pericycle had 2-3 cell layers, while the endodermis was indistinct. Next to the abaxial side of the vascular system 4-6 parenchyma layers and 3-4 angular collenchyma layers were present. Phenolic compounds were detected in some cells of the pith and cortical parenchyma. The epidermis on the abaxial surface was uni-stratified, with partially differentiated cells, which were slightly smaller when compared to those occurring on the adaxial surface. The cuticle was relatively thin and similar to that on the adaxial surface (Fig. 8).

In the lateral vein region, the epidermis was 2-3 layered, covered by a thin cuticle. The cells were larger than those on the midrib. The inner epidermal layer presented larger cells. A large amount of cystoliths were observed, mainly on the adaxial side of the lamina. The partially differentiated mesophyll was made up of nine cell layers, the first with anticlinally elongated cells. Cells with phenolic compounds were frequent. Procambial cells constitute the vascular bundles, where few tracheary elements were differentiated. The endodermis was already differentiated at this stage of leaf development and involved the minor and the major bundles. The pericycle was distinct just involving the larger bundles. On the abaxial side of the lamina, the epidermis was 2-layered and possessed few stomata. Some stomata were not totally differentiated. The cuticle was similar to that on the adaxial surface (Fig. 9).

The early stages of gall development were characterized by the fully expanded leaf lamina. Small reddish to brownish spots, due to $G$. ficorum induction, were visible on the adaxial and abaxial surfaces of the leaf lamina. These small spots were generally concentrated next to the midrib when the infestation was intense (Fig. 1B). Figures 4 and 5 show the lesions on both surfaces. The epidermal cells around the lesions accumulate phenolic compounds. Stomata on the abaxial surface were numerous and differentiated. In some cases, however, stomata development is interrupted, ostiole and guard cell are not formed and/or the subsidiary cells become deformed (Fig. 5).

In the midrib region, the cuticle was thin but somewhat thicker than on the healthy leaf. The epidermis on the abaxial surface showed a higher degree of differentiation, the cells possessing convex periclinal external walls. There was some inhibition in the development of vascular tissues, and at the lateral parenchyma portions a few slightly hypertrophied cells were observed. As a consequence, the midrib region was not convex (Fig. 10). In the region of lateral veins, the tracheary elements of the major veins were differentiated. The mesophyll had more layers (14), with some hypertrophied cells, which generally had phenolic compounds. Because of the hypertrophy of the cells and hyperplasia of the tissues, swelled areas were observed in the lamina (Fig. 11).

The mature gall was characterized by the complete folding of the lamina (Fig. 1C). This folding always occurred next to and along the midrib, and, therefore, half of the adaxial surface was either totally or partially covering the other half. Thus, the larval chamber was formed having permanent communication with the external environment. The majority of the stomata on the abaxial surface showed structural alterations similar to an early stage of gall development and abnormal distribution (Fig. 7). The epidermis had perforations caused by Gynaikothrips mouthparts (Fig. 6). The midrib region presented structural alterations similar but more conspicuous than those seen in the preceding stage. The adjacent portions to the vascular tissues presented hypertrophied parenchyma cells, mainly on the abaxial side of the lamina, and cells with phenolic compounds were numerous (Fig. 12). In the region of the lateral veins of the galled portions, the mesophyll was disorganized due to hypertrophy of the cells and hyperplasia of the tissues. Many of the cells were rich in phenolic compounds. On the abaxial 

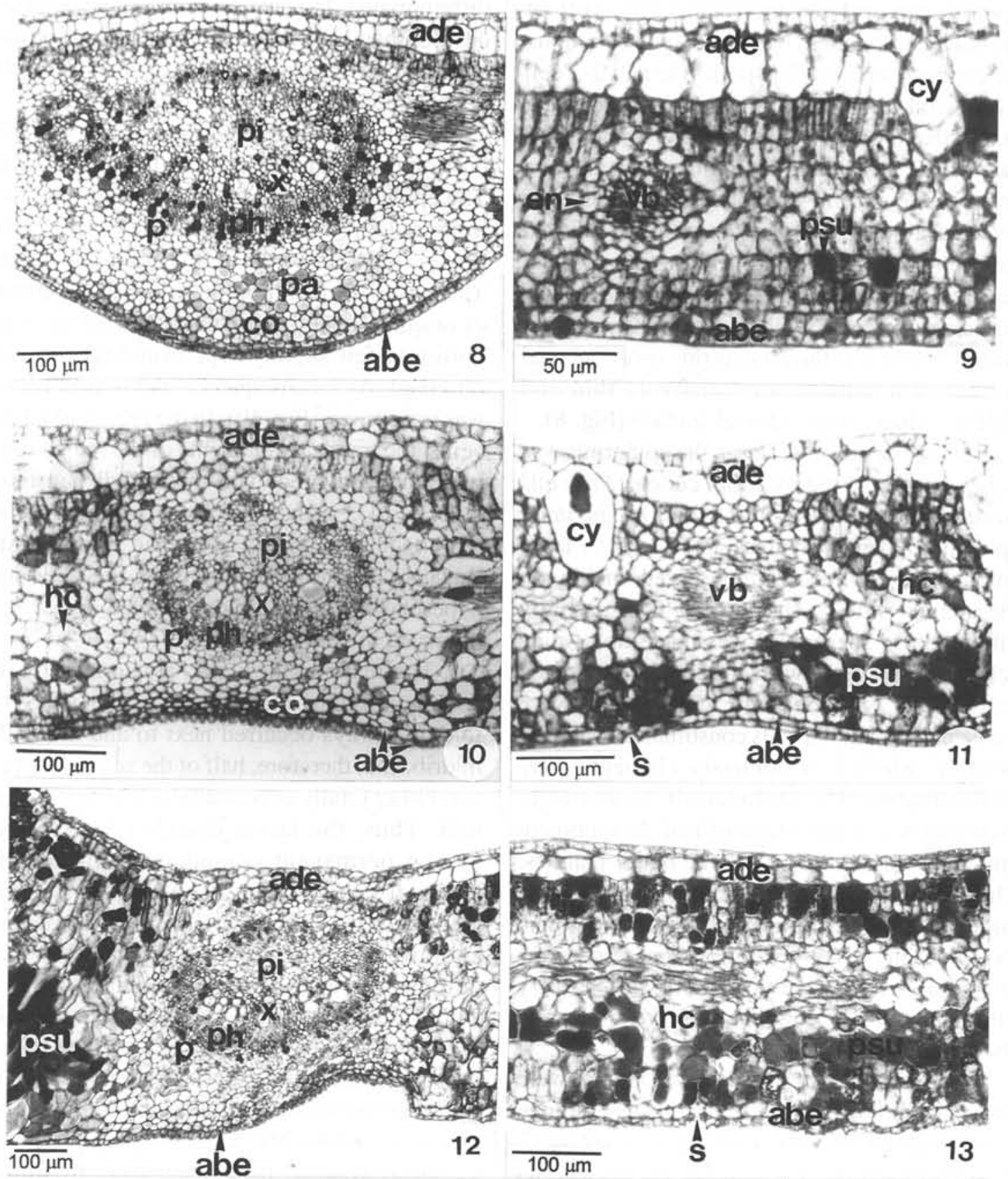

Figures 8-13. Young leaves of Ficus microcarpa (transverse sections). 8. Midrib region of the healthy leaf; 9. Lateral veins region of the healthy leaf; 10 . Early stage of gall development at the midrib region; 11 . Early stage of gall development at the lateral veins region. Note the presence of hypertrophied cells, hyperplasia of the tissues and cells with phenolic compounds; 12. Mature gall at the midrib region showing the lack of the rib; 13. Mature gall on the lateral veins region showing hypertrophied cells on the abaxial surface. Note the presence of numerous cells with phenolic compounds. (abe $=$ abaxial epidermis; ade $=$ adaxial epidermis; $c o=$ collenchyma $; c y=$ cystolith $;$ en $=$ endodermis $;$ hc $=$ hypertrophied cell $; \mathrm{p}=$ pericycle $; \mathrm{pa}=$ parenchyma; $\mathrm{ph}=$ phloem; $\mathrm{pi}=\mathrm{pith} ; \mathrm{psu}=$ phenolic substance $\mathrm{s}=$ stoma; $\mathrm{vb}=$ vascular bundle; $\mathrm{x}=$ xylem). 
surface, alterations were more conspicuous, especially cell hypertrophy (Fig. 13). Similar to the preceding stage, leaf lamina exhibited several swollen areas, probably due to the action of the galling insect.

In general, during gall development, leaf lamina became thicker and in mature galls there was a larger number of injured areas when compared to those in the initial stage of development. That half of the lamina which folded over the other lamina, presented a larger concentration of injured areas.

Healthy and galled mature leaves - Mature and healthy leaves showed a dark green color, coriaceous texture, and were on an average 5.8 $\pm 3.1 \mathrm{~cm}$ long and $3.1 \pm 0,4 \mathrm{~cm}$ wide (Fig. 1D). There were conspicuous differences between the adaxial and the abaxial side of the lamina when compared to the young healthy leaf. Trichomes were scarce or absent on both lamina surfaces (Fig. 14 and 15). Figure 15 shows a larger density of differentiated stomata and a trichome on the abaxial surface. The subsidiary cells were situated above the guard cells, and presented cuticular projections which covered the guard cells partially (Fig. 16).

In the midrib region of the mature healthy leaf, the epidermis on the adaxial surface was 2-3 layered, similar to the young leaf. Nevertheless, the epidermis of mature leaves was covered by a thicker cuticle, $1 / 4$ the height of the cell. The inner layer had larger cells. Below the epidermis, there were 2-3 layers of small parenchyma cells, which were continuous up to the palisade parenchyma. About 3-4 layers of lignified pericyclic fibers involved the vascular system, which was composed of primary and secondary xylem and phloem, and cambium. The vascular system presented a round shape and was formed by two arcs, one abaxially placed, which was larger and continuous, and a smaller one, adaxially placed. Below the vascular system, there were three layers of parenchyma cells and 3-4 layers of angular collenchyma cells. The endodermis was indistinct. On the abaxial surface, the cuticle was thicker than that on the adaxial surface. The epidermis was uni-stratified and the cells had convex periclinal walls (Fig. 21).

The epidermis covered the region of the lateral veins with 2-3 layers in the adaxial surface of the lamina. Epidermal cells were larger than those on the midrib region. The palisade parenchyma was 2-layered. The first layer had anticlinally elongated cells, with few intercellular spaces; the cells of the second layer were shorter and presented small intercellular spaces. Five to seven cell layers with larger intercellular spaces formed the spongy parenchyma; the cells of the inner layer were more closely disposed. The epidermis on the abaxial side of the lamina had two layers and a higher density of stomata (Fig. 22). In the major veins, the cells of the endodermis were sclerified and larger than those on the minor veins. Bundle sheath extensions with sclerified cells were present.

The early stages of gall development were characterized by fully expanded lamina, with small reddish to brownish spots on the abaxial (Fig. 1E) and adaxial surfaces. Even though these spots were visible, they were less distinct when compared to the young leaves, because of the dark green color of the lamina. The spots tended to concentrate next to the midrib when the degree of infestation had increased, similar to what is found in young leaves. Figures 17 and 18 show the lesions which accumulated phenolic compounds on the adjacent cells. The cell walls of the adaxial surface are thicker (Fig. 17). Altered stomata are also present on the abaxial surface (Fig. 18).

In transverse sections, no great alterations were observed on the midrib region of galled leaves in comparison to healthy ones. A discrete inhibition of the development of ones vascular tissues was observed, similar to what was observed in young leaves. The pericyclic fibers were still alive and less lignified (Fig. 23). In 

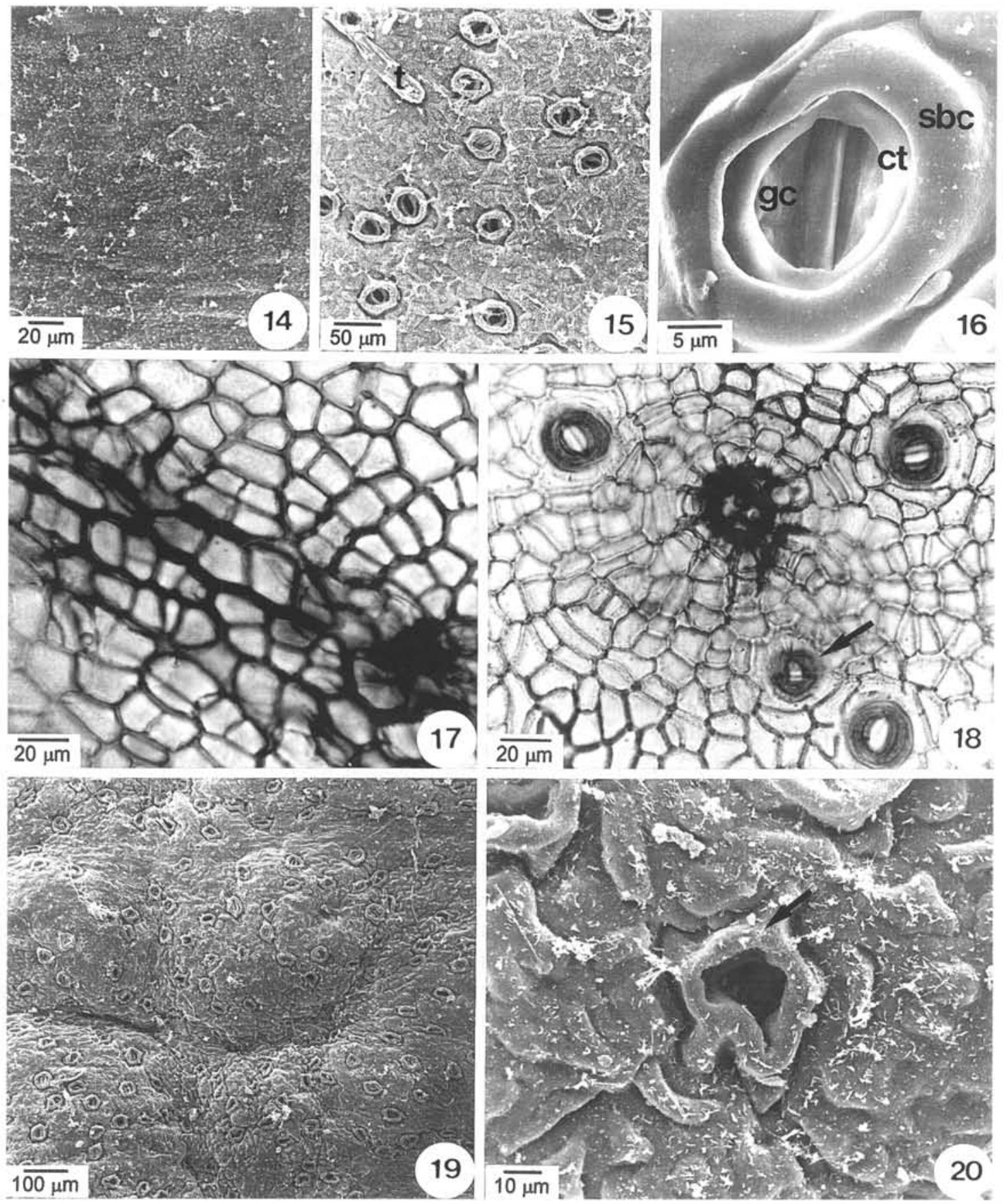

Figures 14-20. Mature leaves of Ficus microcarpa. 14-16, 19 and 20 (SEM). 14. Healthy leaf on the adaxial surface; 15. Healthy leaf showing stomata on the abaxial surface. Note a trichome; 16. Detail of the stoma of the healthy leaf; 17. Early stage of gall development on the adaxial surface. Note the lesion; 18. Early stage of gall development showing a lesion and the altered stoma (arrow) on the abaxial surface; 19. Mature gall showing the swellings of the lamina on the abaxial surface; 20 . Mature gall showing a modified stoma (arrow) on the abaxial surface. ( $\mathrm{ct}=$ cuticular projection; gc $=$ guard cell $; \mathrm{sbc}=$ subsidiary cell $; \mathrm{t}=$ trichome $)$. 

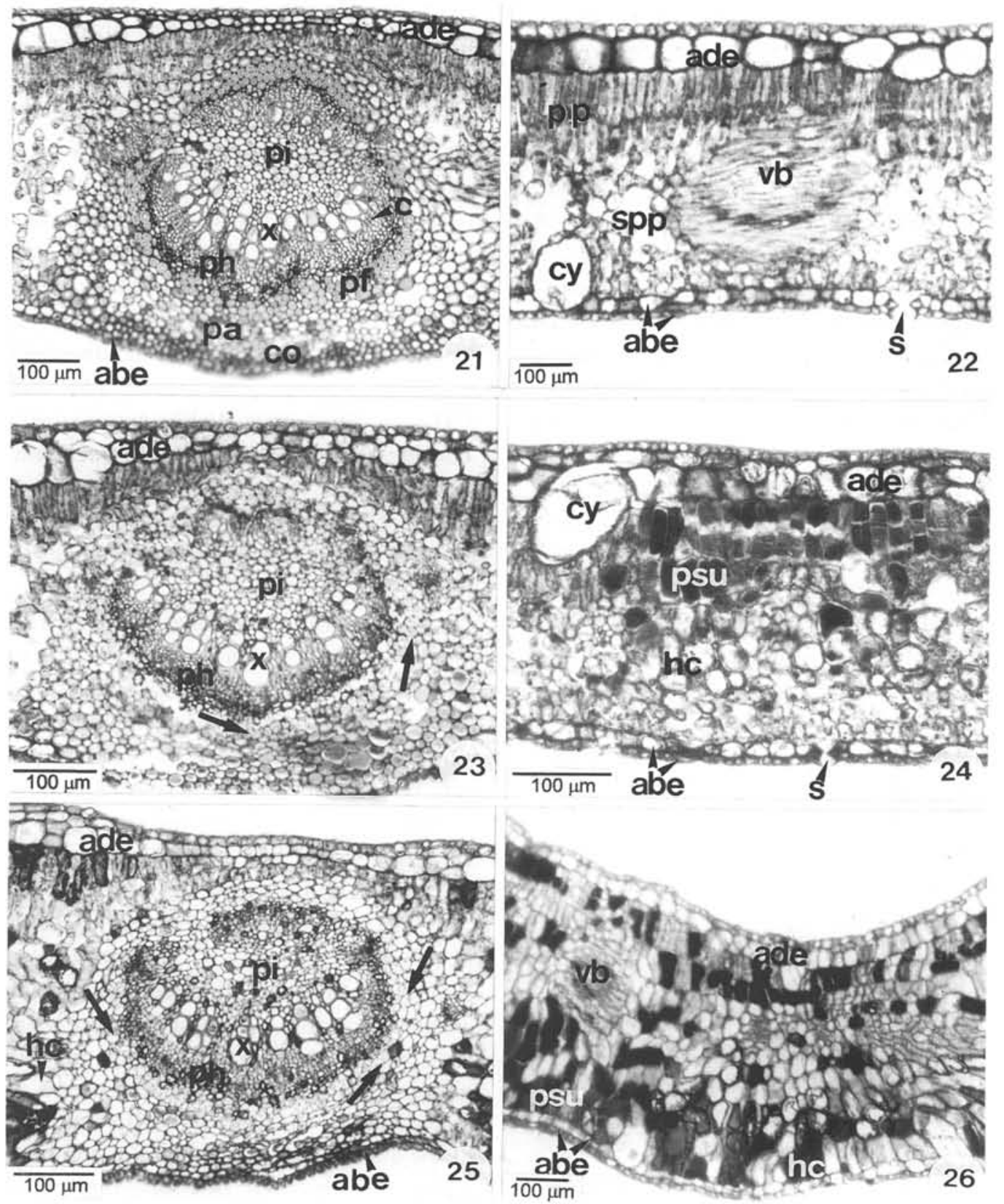

Figures 21-26. Mature leaves of Ficus microcarpa (transverse sections). 21. Midrib region of the healthy leaf; 22. Lateral vein region of the healthy leaf; 23 . Early stage of gall development at the midrib region; 24 . Early stage of gall development at the lateral vein region. Note the presence of the pericyclic fibers less lignified (arrows), cells with phenolic compounds and hypertrophied cells; 25 . Mature gall at the midrib region showing the lack of the rib. Note the absence of the lignified pericyclic fibers (arrows); 26. Mature gall at the lateral vein region. Note the presence of numerous hypertrophied cells on the abaxial surface and cells with phenolic compounds. (abe = abaxial epidermis; ade = adaxial epidermis; $\mathrm{c}=$ cambium $; \mathrm{co}=$ collenchyma cy = cystolith; $\mathrm{pa}=$ parenchyma; $\mathrm{pf}=$ pericyclic fiber; $\mathrm{hc}=$ hypertrophied cell $; \mathrm{ph}=$ phloem $; \mathrm{pi}=$ pith $; \mathrm{pp}=$ palisade parenchyma; $\mathrm{psu}=$ phenolic substance $; \mathrm{s}=$ stoma $; \mathrm{spp}=$ spongy parenchyma; $\mathrm{vb}=$ vascular bundle; $\mathrm{x}=$ xylem). 
the lateral vein region, the mesophyll showed hyperplasia and some of its cells were hypertrophied, leading to the reduction of intercellular spaces (Fig. 24). The swellings of the leaf lamina on mature galled leaves were less evident when compared to those of young ones.

Galls in the mature stage were characterized by the folded leaf along the midrib forming the larval chamber, similar to what was observed in the young leaf (Fig. 1F). Galls were very hard but broke easily. On the abaxial surface the swollen areas were evident and the stomata presented morphological modifications (Fig. 19). An altered stoma is seen in Figure 20.

In the midrib region of the mature galled leaf, the vascular system did not show great alterations when compared to the preceding stage. Parenchyma cells showed some hypertrophy, and most of the pericyclic fibers were not lignified. Cells with phenolic compounds were present (Fig. 25). Because of hyperplasia and hypertrophy next to the midrib, the rib was not formed. In the lateral vein region, cell hypertrophy was concentrated on the abaxial side of the lamina while tissue hyperplasia was concentrated on the adaxial side. Both phenomena were intensified in this region. On the adaxial side, cells with phenolic compounds were more common (Fig. 26). The swollen areas on the leaf surface were conspicuous.

During gall development leaf thickening occurred, similar to what was observed on young leaves. Areas with all the morphological alterations already described were more numerous on the mature galls, and were more concentrated on the folded portions next to the midrib.

\section{Discussion}

Mound et al. (1980) referred to at least 6.000 known species of thrips in the world, and stated that the majority occurred in the tropics. Many species have received attention because they are pests on plants of economical interest (Ananthakrishnan 1992). According to Carrera
(1967), there are several species of Thysanoptera that produced galls in several plants, such as Gynaikothrips ficorum, which infested Ficus microcarpa. In Brazil, the first study describing the attack by $G$. ficorum on Ficus was that of Amante \& Almeida (1962), which erroneously identified the plant species as $F$. retusa var. nitida Thunb. Meyer (1987) also stated that $G$. ficorum is the galling agent in $F$. retusa, and calls attention to the importance of this insect because of its relatively large geographic distribution in Marrocos, Argelia, Israel, India and Malaysia. All the information available on this species was that the small insects made the thickening and folding of the leaf lamina next to the midrib, and formed a larval chamber, where they were found at different developmental stages (Meyer 1987).

In this study, we have confirmed that $G$. ficorum attacks young and mature leaves of $F$. microcarpa. Rohfritsch (1992) stated that young tissues are more sensitive to the induction than mature tissues. Therefore, the author concluded that it was an error to generalize that only meristematic or young tissues react to gall inducer attacks. The studied galling species is an example of this process.

The early stages in the development of $G$. ficorum galls on $F$. microcarpa were characterized by the unfolded lamina with spots on the epidermis. These spots were visible on both surfaces of the leaf, both on young or mature leaves. These spots presented a reddish to brownish color, and this color might be due to the accumulation of phenolic compounds in some cells located in these regions. Small perforations were also observed on the leaf surface. According to Meyer (1987), the Thysanoptera have sucking and rasping mouthpieces, which cause lesions to the plants by perforations, introducing saliva into plant tissues. It was known that mechanical lesions and/or the liberation of substances by the insects might cause gall induction, which alters the development and differentiation of plant tissues 
(Mani 1964; Meyer \& Maresquelle 1983; Hori 1992).

In young leaves of $F$. microcarpa the vascular system was differentiated just in the midrib region, where the lignified pericyclic fibers were absent. Generally, lignification of the tissues was incipient, contributing to the flexibility of the leaf lamina. In contrast, the presence of lignified pericyclic fibers around the vascular tissues of the mature leaf might contribute to its rigidity.

An anatomical analyses of the mature healthy leaf of $F$ microcarpa showed many similarities to the previous observations made by Mello Filho et al. (1983). These authors considered the leaves as glabrous, nevertheless, our SEM observations evidenced the presence of some trichomes on the adaxial and abaxial surfaces of mature leaves, and their conspicuous presence on young leaves, indicating that during organogenesis they were lost. Mello Filho et al. (1983) refer to a hypodermis and a simple epidermis on the abaxial surface, but did not describe them. Here we observed that the abaxial epidermis on the region of the midrib is unistratified, but becomes bi-stratified in the region of the lateral veins. Thus, the layer considered hypodermis is, in reality, an epidermal layer.

Meyer (1987) described that very often the epidermis on galls caused by thysanopterans became necrotic and disintegrated. In $F$. microcarpa galls, the disintegrated and necrotic areas were observed which might be considered cell reactions to the feeding activity of $G$. ficorum.

In galls, the swollen areas of the lamina observed in young and mature leaves coincided with the areas of cellular hypertrophy and tissue hyperplasia. These swellings were detected in a larger amount and more precociously in young leaves. In young leaves, the presence of less differentiated cells, possibly allowed a greater number of cell divisions and, thus, the swellings might in part be due to this characteristic. Moreover, the minor quantity of cells with lignified walls in young leaves might also have favored cell hypertrophy.

In young healthy leaves, few differentiated stomata were observed in the epidermis, differing from the tissues of the gall, where they were already differentiated, more numerous and with structural alterations. Thus, cecidogenesis induced a quicker differentiation of stomata, and also altered the normal development of the guard and subsidiary cells. In the mature galled leaf, stomata predominantly presented less alteration, due to the stomata having already been differentiated before the insect attack. On young and adults galled leaf stomata distribution is also modified. Meyer \& Maresquelle (1983) described that epidermal cells on the abaxial surface of the galled leaf as being hypertrophied and the stomata less numerous. These authors, therefore, did not define whether the leaves were young or mature. In $F$ microcarpa gall, the smaller number of stomata observed on some regions could be caused by the greater distance of the cells as an consequence of cell hyperplasia or hypertrophy of the non-specialized epidermal cells.

Leaf folding causing the formation of the larval chamber in mature galls, even in young or mature leaves, might be due to the more pronounced structural alterations in this stage. As the majority of insect attacks occur near the midrib, leaf folding in this region may be a consequence of this attack. In this gall there generally were no alterations in the leaf margin. In the affected region, cell hypertrophy was more conspicuous on the abaxial portion of the leaf, causing leaf folding. At this stage of gall development, the mesophyll was totally disorganized, being compact, without intercellular spaces, with numerous hypertrophied cells containing a great amount of phenolic compounds.

The presence of phenolic compounds in tissues of the galls is very frequent (Mani 1964; Meyer \& Maresquelle 1983; Rohfritsh 1992) and has been confirmed in several studies (Arduin 
et al. 1991; Arduin \& Kraus 1995; Kraus et al. 1996). The presence of phenolic compounds is known as a defense against herbivory (Levin 1971; Feeny 1976; Harborne 1990) and it might be proposed that these substances should basically favor the inducer against parasitoids and predators or against fungi and microorganisms infestation (Cornell 1983; Rhoades 1985). Besides their defensive role, phenolic compounds are also involved in hormonal regulation. The presence of these compounds should inhibit indoleacetic acid oxidases (IAA-oxidases), increasing the auxin action responsible for cell hypertrophy (Bhansali et al. 1978; Hori 1992). The quantification of phenolics, auxin and related enzymes in the galls of $F$. microcarpa has not been studied yet.

The absence of lignified cells, as well as pericyclic fibers in mature galls formed either in young or mature leaves might involve different processes. In young leaves the results indicated that there was an inhibition of the differentiation of the pericyclic fibers, while in mature leaves there might be the degradation of the lignified wall. According to Herms \& Mattson (1992), phenilalanin is the limiting precursor for the synthesis of such phenilpropanoids as lignin, flavonoids, and condensed tannins, indicating that these were derived from the same metabolic route. In young leaves, we propose that there was a prioritization for the formation of soluble phenolic compounds in detriment of lignin production. Otherwise, in mature leaves, the degradation of lignin in the wall of pericycle derivatives is unexplained. Therefore, more detailed studies are required to explain our hypothesis. On the other hand, it is known that there are mechanical and chemical investments in defensive compounds in galls (Cornell 1983) and so, the presence of a great quantity of phenolics should corroborate the chemical investment of $F$. microcarpa gall.

The fact that the tissues of young and mature leaves responded to the stimuli of $G$. ficorum is an indication that these tissues, independent of the stage of development, acquired competence for cecidogenesis. In young leaves of $F$. microcarpa, cecidogenetic responses were faster and led to more structural differences since the cells were not completely differentiated. Moreover, it should be taken into consideration that the development of the gall was related not only to the stage of development of the host organ, but also to the number of insects present, sites of feeding, etc., as was proposed by Ananthakrishnan (1980 apud Rohfritsch 1992).

$G$. ficorum might use young as well as mature tissues of $F$ microcarpa for its feeding and oviposition activities, indicating a high level of interaction between host and parasite. The structural modifications in leaf tissues resulted in galls that were very simple and where cell hypertrophy and tissue hyperplasia were involved in their morphogenesis. These two processes were generally observed, in the formation of some other galls caused by thrips (Rohfritsch 1992; Ananthakrishnan 1992). F. microcarpa gall study was also relevant because the cecidogenetic action by $G$. ficorum was extensive, and involved the entire leaf lamina. Nevertheless, in spite of the numerous sites of feeding and the wide area of attack, $F$. microcarpa galls can be considered rudimentary as no new tissue differentiation was observed.

\section{Acknowledgments}

This investigation was supported by $\mathrm{CNPq}$ (301776/83 and PIBIC N/108362/95-7) and CAPES/ PICDT research grants.

\section{References}

Amante, E. \& Almeida, E. 1962. Insetos que ocorrem em Ficus retusa e Ficus benjamina. Arquivos do Instituto Biológico 29: 93-101.

Ananthakrishnan, T. N. 1992. Unique aspects in the biology of thrips-induced galls. Pp. 185-195. In: J. D. Shorthouse \& O. Rohfritsch (Eds.), Biology of insectinduced galls. Oxford University Press, New York.

Arduin, M.; Kraus, J. E. \& Venturelli, M. 1991. Estudo morfológico de galha achatada em folha de Struthanthus vulgaris Mart. (Loranthaceae). Revista Brasileira de Botânica 14: 147-156. 
Arduin, M. \& Kraus, J. E. 1995. Anatomia e ontogenia de galhas foliares de Piptadenia gonoacantha (Fabales, Mimosaceae). Boletim de Botânica, Universidade de São Paulo 14: 109-130.

Bhansali, R. R.; Kumar, A. \& Arya, H. C. 1978. Polyphenols and related enzymes in normal and gall tissues of Ficus mysorensis Heyne. Indian Journal of Experimental Biology 16: 850-851.

Carrera, M. 1967. (Ed.) Ordem dos Tisanópteros. Pp. 5455. In: Entomologia para você. $3^{a}$. ed. EDART Livraria Editora Ltda., São Paulo.

Condit, I. J. 1969. Ficus: the exotic species. University of California Press, Arcadia.

Cornell, H. V. 1983. The secondary chemistry and complex morphology of galls formed by Cynipidae (Hymenoptera): why and how? The American Midland Naturalist 110: 225-234.

Feeny, P. 1976. Plant apparency and chemical defense. Pp. 1-40. In: G. W. Wallace \& R. L. Mansell (Eds.), Biochemical interaction between plants and insects. Plenum Press, New York.

Fernandes, G. W. \& Price, P. W. 1988. Biogeographical gradients in galling species richness: tests of hypotheses: Oecologia 76: 161-167.

Ghouse, A K. M. \& Yunus, M. 1972. Preparation of epidermal peels from leaves of gymnosperms by treatment with hot, $60 \% \mathrm{HNO}_{3}$. Stain Technology 47 : 322-324.

Harborne, J.B. 1990. Constraints on the evolution of biochemical pathways. Biological Journal of Linnean Society 39: 135-151.

Herms, D. A. \& Mattson, W. J. 1992. The dilemma of plants: to grow or defend. The Quarterly Review of Biology 67: 283-335.

Hori, K. 1992. Insect secretions and their effect on plant growth, with special reference to hemipterans. Pp. 157170. In: J. D. Shorthouse \& O. Rohfritsch (Eds.), Biology of insect-induced galls. Oxford University Press, New York.

Johansen, D. A. 1940. Plant microtechnique. McGrawHill Book Co, New York.

Kraus, J. E.; Sigiura, H. C. \& Cutrupi, S. 1996. Morfologia e ontogenia em galhas entomógenas de Guarea macrophylla subsp. tuberculata (Meliaceae). Fitopatologia Brasileira 21: 349-356.

Kraus, J. E. \& Arduin, M. 1997. Manual básico de métodos em morfologia vegetal. Editora Universidade Rural, Seropédica.

Kraus, J. E.; Sousa, H. C.; Rezende, M. H., Castro; N. M., Vecchi, C. \& Luque, R. 1998. Astra blue and basic fuchsin double staining of plant materials. Biotechnic \& Histochemistry 73: 235-243.
Levin, D. A. 1971. Plant phenolics: an ecological perspective. The American Naturalist 105: 157-181.

Mani, M. S. 1964. Ecology of plant galls. Dr. W. Junk Publishers, The Hague.

Mello Filho, L. E.; Neves, L. J. \& Caldas, R. L. S. 1983. Anatomia foliar de Ficus microcarpa L. f. (Moraceae). Bradea 3: 387-398.

Meyer, J. 1987. Plant galls and galls inducers. Gebrüder Borntraeger, Berlin.

Meyer, J. \& Maresquelle, H. J. 1983. Anatomie des galles. Gerbrüder Borntraeger, Berlin.

Mound, L. A.; Heming, B. S. \& Palmer, J. M. 1980. Phylogenetic relationships between the families of recent Thysanoptera. Zoological Journal of Linnean Society 69: 111-141.

Neves, L. J. 1987. Morfologia, desenvolvimento e anatomia de Ficus tomentella Miq. (Moraceae). Tese de Doutorado, Universidade de São Paulo, São Paulo.

Neves, L. J. \& Isaias, R. M. S. 1987. Ocorrência de agente galhador em flores de Ficus microcarpa L. f. Bradea 4: $327-330$.

Price, P. W.; Waring, G. L. \& Fernandes, G. W. 1986. Hypotheses on the adaptive nature of galls. Proceedings of Entomological Society of Washington 88: 361-363.

Price, P. W.; Fernandes, G. W. \& Waring, G. L. 1987. Adaptative nature of insect galls. Environmental Entomology 16: 15-24.

Raman, A. \& Gopinathan, Ke 1987. On the structure and morphogenesis of leaf galls of Ficus religiosa Linn. (Moraceae) induced by Pipaldiplosis pipaldiplosis Mani (Cecidomyiidae: Diptera). Beiträge zur Biologie der Pflanzen 62: 69-77.

Rhoades, D. F. 1985. Offensive-defensive interactions between herbivores and plants: their relevance in herbivore population dynamics and ecological theory. The American Naturalist 125: 205-238.

Rohfritsch, O. 1992. Patterns in gall development. Pp. 6086. In: J. D. Shorthouse \& O. Rohfritsch (Eds.), Biology of insect-induced galls. Oxford University Press, New York.

Silveira, M. 1989. Preparo de amostras biológicas para microscopia eletrônica de varredura. Pp. 71-90. In: W. Souza (Ed.), Manual sobre técnicas básicas em microscopia eletrônica. Sociedade Brasileira de Microscopia Eletrônica, Rio de Janeiro. 